\title{
New Record of Anthracnose Disease of Pleomele (Dracaena reflexa Lam.) from West Bengal, India
}

\author{
Arghya Banerjee*, Saidul Islam, Rahamatulla Middya and Partha Sarathi Nath
}

Department of Plant Pathology, Bidhan Chandra Krishi Viswavidyalaya, Mohanpur, Nadia, -741252, W.B., India

*Corresponding author

\section{A B S T R A C T}

\begin{tabular}{|c|c|}
\hline Keywords & $\begin{array}{l}\text { Occurrence of anthracnose disease of Pleomele (Dracaena reflexa Lam.) is first time } \\
\text { observed during mid-August to October, 2017, from nursery garden of Salt lake City, }\end{array}$ \\
\hline $\begin{array}{l}\text { Pleomele, } \\
\text { Dracaena reflexa, } \\
\text { Anthracnose, } \\
\text { Colletotrichum } \\
\text { gloeosporioides, } \\
\text { West Bengal. }\end{array}$ & $\begin{array}{l}\text { Kolkata, West Bengal, India. Typical small to medium sized light grey - white spots } \\
\text { surrounded by irregular dark brown zonate margin with numerous production of concentric } \\
\text { brown to black dot like stromatic structures are observed on the upper surface of leaves. } \\
\text { Based on cultural, morphological, vegetative and reproductive structures, the causal } \\
\text { pathogen of anthracnose disease is identified as Colletotrichum gloeosporioides which is } \\
\text { being considered as new record from West Bengal. Spores of Colletotrichum }\end{array}$ \\
\hline Article I & \\
\hline $\begin{array}{l}\text { Accepted: } \\
12 \text { October } \\
\text { Available } O \\
10 \text { Decembe }\end{array}$ & $\begin{array}{l}\text { 4.4) } \mu \text {. The hyphae produced are hyaline, thin and septate, varied from } 10.5-14.2 \text { (av. } \\
\text { 13.2) } \mu \text { in diameter. Acervuli are pale brown to black, } 133.5-195.1 \text { (av.167.2) } \mu \text { in size } \\
\text { with numerous, black to dark brown, } 1-3 \text { septate, unbranched, } 10.1-13.3 \text { (av. 12.0) x } \\
3.0-3.8 \text { (av. 3.4) } \mu \text { sized pointed setae. }\end{array}$ \\
\hline
\end{tabular}

\section{Introduction}

Dracaena reflexa (family- Asparagaceae), commonly called Pleomele or Song of India, is a species of Dracaena which is a tropical plant native to Madagascar, Mauritius and other nearby islands of the Indian Ocean. It is widely grown as an ornamental plant and houseplant, valued for its richly coloured, evergreen, variegated leaves and thick, irregular stems. Traditional medicine practitioners of Madagascar have long believed Dracaena reflexa to cure malarial symptoms, poisoning, dysentery, diarrhea, dysmenorrhea and to be useful as an antipyretic and haemostatic agent (c.f. Randrianarivelojosia et al., 2003). It has also the capacity to remove a considerable amount of toxins from the environment. On literature surveyed, it has been found that the genus Dracaena is attacked by at least 15 fungal, 1 bacterial, 2 viral and 3 nematode diseases as reported from India and different parts of the world. But there was only one record of bacterial leaf spot disease caused by Burkholderia gladioli on Dracaena reflexa from New Zealand (Romberg et al., 2010).

Several species of Dracaena were known to be attacked by anthracnose disease caused by Gloeosporium and Colletotrichum spp. Leaf spot of Dracaena hookeriana was reported 
from Chandigarh caused by Gloeosporium polymorphum (c.f. Sohi, 1990). Serious damage by anthracnose (Colletotrichum gloeosporioides) on greenhouse crops of Dracaena deremensis was first time observed in Italy (Lenna and Montecchio, 1995). Anthracnose of Dracaena fragranci by Colletotrichum gloeosporioides was recorded from China (Wang et al., 1997). Another species, Colletotrichum dracaenophilum on Dracaena sanderiana was described as new from China (Farr et al., 2006), Iran (Komaki et al., 2012) and Egypt (Morsy and Elshahawy, 2016). Antharacnose of Dracaena braunii, caused by Colletotrichum dracaenophilum was also reported from Bulgaria (Bobev et al., 2008), China (Liu et al., 2014) and Brazil (Macedo and Barreto, 2016). There were reports of four species of Colletotrichum in association with $D$ braunii, namely, $\quad C$. dracaenophilum, $C$. gloeosporioides, $C$. petchii (Farr and Rossman, 2012) and C. boninense (Farr et al., 2006). But there is no record on occurrence of anthracnose disease on Dracaena reflexa. From mid-August to October, 2017, it has been found that the plant is suffering severely from anthracnose disease. A detailed study on this disease along with its causal agent has been conducted during present investigation. Objective of this study is to know the intensity and time of occurrence of diseases, pathogenicity establishment and characterization of the pathogen on this plant.

\section{Materials and Methods}

\section{Collection of diseased sample}

Diseased leaves were collected from nursery garden of Salt lake City, Kolkata, West Bengal, India. Typical small to medium sized light grey - white spots surrounded by irregular dark brown zonate margin with numerous production of concentric brown to black dot like stromatic structures were observed on the upper surface of leaf. In severe case, several spot coalesced and total leaves dried up basipetally.

\section{Pure culture isolation}

Diseased leaves were cut into small pieces, surface sterilized in $1 \%$ sodium hypochlorite for 45 - 60 seconds, rinsed three times in sterile distilled water, plated on water agar (Fig. 1D) and then incubated at $28^{\circ} \mathrm{C}$ for 5 days. Hyphal tips from the margin of developing colony were picked up and transferred to potato dextrose agar (PDA) medium for pure culture preparation (Fig. $1 \mathrm{E})$.

\section{Morphological observations}

Series of slides were prepared from cultures or infected parts for morpho-metric studies of fungal spores, spore bearing and other structures. Micro-photograph of all fungal structures was taken with help of Leica Binocular Microscope and or Karl Zeis Phase Contrast Microscope and by using Canon Powers Shot A640 camera. Dimensions of conidia, conidiophore, acervuli with setae were measured using AxioVision (Rel. 4.8) software.

\section{Establishment of pathogenicity}

A pathogenicity test was performed by inoculating healthy leaves with six-day-old purified active fungal culture under controlled laboratory condition. Mycelial and conidial plugs $(5 \mathrm{~mm}$ diameter) were taken from potato dextrose agar (PDA) and placed on detached leaves. The inoculated leaves were kept in moistened plastic bags in the dark for two days and then in natural light at $20^{\circ} \mathrm{C}$. Although the method of inoculation was somewhat artificial, the symptoms were similar to those observed in natural condition and the fungus was reisolated from infected 
parts. The control leaves, inoculated with PDA plugs, remained healthy.

\section{Results and Discussion}

Anthracnose disease of Dracaena occurs regularly in garden houses which ultimately reduce its marketable value. Though the disease occurs throughout the year in different ornamental growing areas, but severity and sporulation of the pathogen was noticed during mid-August to October.

It was observed that $20-35 \%$ leaf area (rating: 4) was covered with spots based on 06 disease scoring scale (McKinny, 1923). The infection began as small, round to oval brown spots with white-grey centres, which generally appeared close to leaf margin and middle portion of leaf (Fig. 1A). As disease progressed, the leaves showed characteristic leaf spot symptoms with light brown to grey coloured necrotic areas bordered by dark brown wavy margins. Upon binocular observation, brown-black, erumpent, dot, 71 92.6 (av. 74.6) $\mu$ sized stromatic mass like structures could be observed from the host tissues (Fig. 1C). On PDA medium the fungus produced cottony white mycelial growth which was slightly convex and dense. Upon observation from below greyish coloured mycelia could be observed. Fluffy mycelial growth covered the media completely with numerous productions of acervuli near the inoculated disc.

On the potato dextrose agar medium, the hyphae produced were hyaline, thin and septate. Its diameter varied from $10.5-14.2$ (av. 13.2) $\mu$. Acervuli were pale brown to black, 133.5 - 195.1 (av.167.2) $\mu$ in size. Setae (Fig. 1G, H) were numerous, black to dark brown, 1 - 3 septate, unbranched, 10.1 13.3 (av. 12.0) x $3.0-3.8$ (av. 3.4) $\mu$ in size with pointed tips. Conidia were hyaline, 1celled, smooth walled, eguttulate, cylindrical with rounded ends measuring 8.2 - 16.8 (av. 12.6) x $3.0-5.5$ (av. 4.4) $\mu$ in size (Fig. 1I). Several species of Dracaena were known to be attacked by Gloeosporium polymorphum and six different species of Colletotrichum, viz., C. dracaenophilum, C. dracaenicola, $C$. gloeosporioides, C. petchii, C. boninense and C. dracaena-fragrantis. The above mentioned description of isolated pathogen was verified with the description of Colletotrichum gloeosporioides given by Saccardo (1884), described as conidiomata were acervulus, amphigenous, mostly epiphyllous, subepidermal.

Fig.1 A. B - Anthracnose disease symptom, C - Microscopic view of acervulus obtained from host, D - Isolation of pathogen, E - Pure culture (on PDA medium), F - Artificial production of acervulus on PDA medium, G, H - Setae, I - Conidia with conidiophores

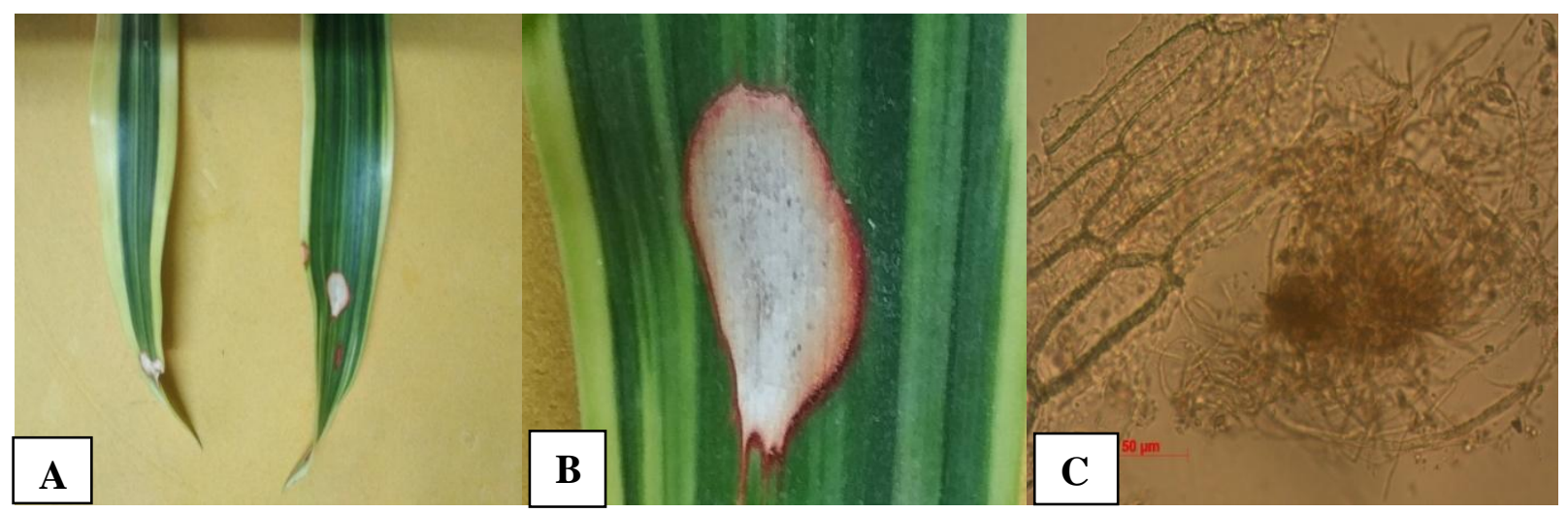




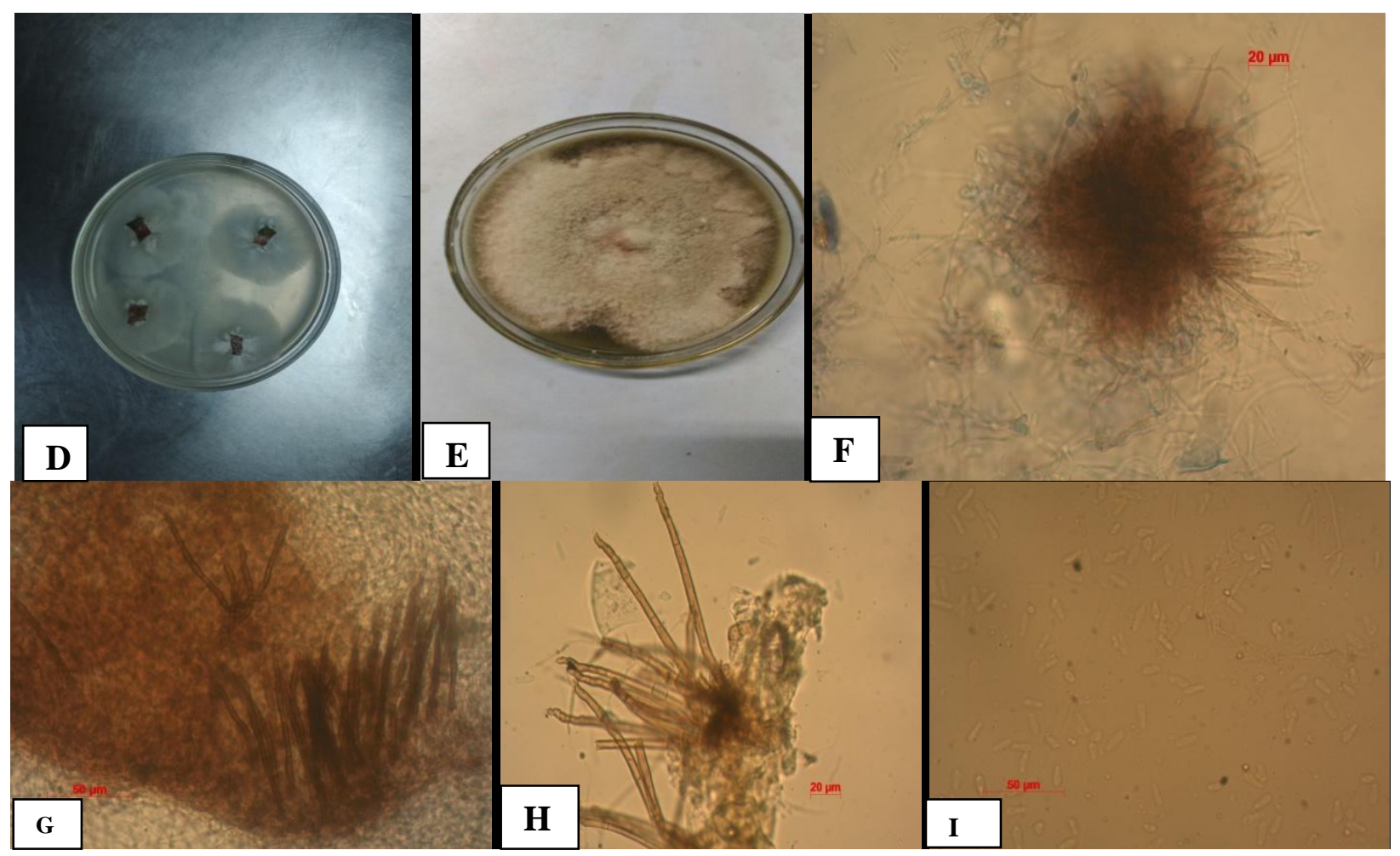

Setae were often present on acervuli but sometimes arising alone from stomata, forming dense fascicles and bearing enteroblastic conidia apically. Conidiogenous cells were discrete, enteroblastic, phialidic, hyaline and smooth. Conidia were slimy, formed singly, cylindrical, (10 -) 15 - 20 (25) $x(3-) 4-6 \mu$ in size, apex obtuse, base sub-acute, aseptate, guttulate, hyaline, smooth, forming septum before germination. Appressoria with entire or sometimes slightly irregularly lobate margin were ovate, globose or ampulliform, brown to medium brown, 8 $12 \times 6-9 \mu$ in size. When the acervuli and conidial characteristics of causal fungal pathogen of the present study were compared with above mentioned anthracnose causing fungal species, it differed from Gloeosporium due to the presence of setae and also from other species of Colletotrichum due to dissimilarity in spore shape and size but exhibit gross similarity with Colletotrichum gloeosporioides. So, the causal fungus of presently described anthracnose disease of Dracaena reflexa is being proposed as
Colletotrichum gloeosporioides. It is the first record of the pathogen from West Bengal.

\section{References}

Bobev, S. G., Castlebury, L. A. and Rossman, A. Y., 2008. First Report of Colletotrichum dracaenophilum on Dracaena sanderiana in Bulgaria. Plant Disease, 92: 173.

Farr, D. F. and Rossman, A. Y., 2012. Fungal Databases, Systematic Mycology and Microbiology Laboratory, ARS, USDA. http://nt.ars-grin.gov/fungaldatabases/

Farr, D. F., Aime, M. C., Rossman, A. Y. and Palm, M. E., 2006. Species of Colletotrichum on Agavaceae. Mycological Research, 110(12): 1395 1408.

Komaki, A. M., Aghapour, B. and Aghajani, M. A., 2012. First report of Colletotrichum dracaenophilum on Dracaena sanderiana. Rostaniha, 13(1): 111- 112.

Lenna, P. di and Montecchio, L., 1995. 
Serious damage by anthracnose (Colletotrichum gloeosporioides) on greenhouse crops of Dracaena deremensis. Informatore Fitopathologico, 45(4): $24-26$.

Liu, F., Cai, L., Crous, P. W. and Damm, U., 2014. The Colletotrichum gigasporum species complex. Persoonia, 33: 83 97.

Macedo, D. M. and Barreto, R. W., 2016. Colletotrichum dracaenophilum causes anthracnose on Dracaena braunii in Brazil. Australasian Plant Disease Notes, 11: 5.

Mckinny, H. H., 1923. A new system of grading plant diseases. Agric. Res., 26: 95-198.

Morsy, A. A. and Elshahawy, I. E. 2016. Anthracnose of lucky bamboo Dracaena sanderiana caused by the fungus Colletotrichum dracaenophilum in Egypt. Journal of Advanced Research. 7(3): 327 - 335.

Randrianarivelojosia, M., Rasidimanana, V. T., Rabarison, H., Cheplogoi, P. K.,
Ratsimbason, M., Mulholland, D. A. and Mauclère, P., 2003. Plants traditionally prescribed to treat tazo (malaria) in the eastern region of Madagascar. Malaria Journal, 2: 25.

Romberg, M. K., Griffin, R. L., Murugan, S., Quinn, B. D. and Alexander, B. J. R., 2010. First Report of Leaf Spot of Dracaena reflexa Caused by Burkholderia gladioli Worldwide. Plant Disease, 94(6): 781.

Saccardo., $\quad 1884 . \quad$ Colletotrichum gloeosporioides Penz. Penz. \& Sacc., Atti R. Ist. Ven. Sci. Lett. Art., Ser., 2: 6.

Sohi, H. S., 1990. Diseases of ornamental plants in India, Publications and Information Division, Indian Council of Agricultural Research, New Delhi. p.198.

Wang, Z. H., Wang, B. H., Lin, S. and Chen Z. X., 1997. Some records of mycotic leaf spots in Fujian. Journal of Fujian Agricultural Universty, 26(3): 303 307.

\section{How to cite this article:}

Arghya Banerjee, Saidul Islam, Rahamatulla Middya and Partha Sarathi Nath. 2017. New Record of Anthracnose Disease of Pleomele (Dracaena reflexa Lam.) from West Bengal, India. Int.J.Curr.Microbiol.App.Sci. 6(12): 1394-1398. doi: https://doi.org/10.20546/ijcmas.2017.612.156 